\title{
Influence of stearoyl-coenzyme A desaturase 1 genotype and stage of lactation on fatty acid composition of Canadian Jersey cows
}

\author{
P. M. Kgwatalala, E. M. Ibeagha-Awemu, A. F. Mustafa, and X. Zhao ${ }^{1}$ \\ Department of Animal Science, McGill University, 21,111 Lakeshore Road, Ste-Anne-De-Bellevue, Quebec, H9X 3V9, Canada
}

\begin{abstract}
Bovine milk contains high proportions of saturated fatty acids (SFA) because of the extensive biohydrogenation of dietary fatty acids in the rumen. Stearoylcoenzyme A desaturase 1 (SCD1) catalyzes the conversion of $\mathrm{C} 10$ to $\mathrm{C} 18$ SFA into their monounsaturated (MUFA) counterparts in the mammary glands of ruminant animals; and 2 alleles ( $A$ and $V$ ) have previously been identified at the $S C D 1$ locus. Genotypes at this locus were identified and fatty acid contents of milk were measured for 525 Canadian Jersey cows. Association analysis indicated that allele $A$ is positively associated with higher C10 (C10I), C12 (C12I) and C14 (C14I) indices and, consequently, with greater contents of $\mathrm{C} 10: 1$ and $\mathrm{C} 12: 1$, but not C14:1, relative to allele $V$. Allele $A$ was also positively associated with increased 305-d milk and protein yields. Allele $A$, however, had no influence on C16 (C16I), C18 (C18I), or conjugated linoleic acid indices (CLAI) compared with the $V$ allele. Stage of lactation had an influence on desaturase indices and consequently on the MUFA contents of milk fat. The indices C10I, C12I, C14I, and CLAI increased from early to mid lactation as did their respective MUFA. Genetic selection for increased unsaturation of the hypercholesterolemic fatty acids in milk fat is feasible and may be accompanied by increased lactation milk and protein yields.
\end{abstract}

Key words: stearoyl-CoA desaturase 1, desaturase index, fatty acid composition, Jersey

\section{INTRODUCTION}

Milk fat composition is one of the factors influencing the technological and nutritional quality of dairy products (Chilliard et al., 2003). Apart from their quantitative contribution to the amount of dietary energy, different fatty acids in dairy and dairy products are potentially involved as positive or negative predisposing factors for the health of human consumers (Parodi,

Received June 20, 2008

Accepted October 27, 2008.

${ }^{1}$ Corresponding author: xin.zhao@mcgill.ca
1999; Williams, 2000). Bovine milk typically contains $70 \%$ saturated fatty acids (SFA), $25 \%$ monounsaturated fatty acids (MUFA), and 5\% polyunsaturated fatty acids (PUFA; Grummer, 1991). Results from epidemiologic, clinical, and animal studies indicate that high quantities of dietary SFA, as is the case with bovine milk, can lead to an increase in blood cholesterol and, consequently, an increased risk of atherosclerosis and coronary heart disease in humans (German et al., 1997; Kromhout et al., 2002). On the contrary, MUFA and PUFA have been reported to decrease both serum total cholesterol and low-density lipoprotein cholesterol levels and therefore reduce the risk of coronary heart diseases (Kris-Etherton et al., 1999; Mensink et al., 2003). It is now commonly accepted that the cholesterol-raising effects of SFA in bovine milk are confined to the mediumchain fatty acids: lauric (C12:0), myristic (C14:0), and palmitic (C16:0) acids, whereas the short-chain (C4:0 to C8:0) and some medium-chain (C10:0) saturated fatty acids are reported to be neutral, with $\mathrm{C} 18: 0$ reportedly as effective as C18:1 in reducing plasma cholesterol levels (Bonanome and Grundy, 1988).

A more favorable combination of bovine milk lipids to human health would be around 30\% SFA, 60\% MUFA, and 10\% PUFA (Hayes and Khosla, 1992; Pascal, 1996), so the current composition is far from optimal. Manipulating animal nutrition is currently the method of choice for modifying the fatty acid composition of milk fat toward the ideal composition. But even the most extreme modification of the diet by itself will not be sufficient to achieve the desired milk fat composition (Grummer, 1991). The applications of current knowledge of cattle genetics and controlled nutrition of dairy cows have been suggested to be prevailing methods for improving milk fat composition (Goddard, 2001). The application of genetic knowledge for the optimization of milk fat composition is possible on the basis of genetic variability and heritability of milk fat composition both between breeds and within breeds (Soyeurt et al., 2006; Stoop et al., 2008).

In ruminant animals, one of the key enzymes having significant influence on milk fatty acid composition is stearoyl-CoA desaturase 1 (SCD1). Stearoyl-CoA desaturase 1 catalyzes the conversion of saturated fatty 
acids with 10 to 18 carbon atoms into their monounsaturated counterparts and is also accredited with the synthesis of most of the conjugated linoleic acid (CLA) in the mammary gland of ruminant animals. Conjugated linoleic acid is of interest to human health because it may be anticarcinogenic and antiatherosclerotic, may decrease fat accumulation, and can modulate the immune response (Pariza et al., 1999; MacDonald, 2000). Therefore, an alternative way to study the nutritional quality of milk fat is to analyze the variations in SCD1 activity (Soyeurt et al., 2006). The SCD1 activity, also known as the desaturase index, can be estimated by calculating the product to substrate ratio for the different fatty acids that SCD1 catalyzes; a higher index translates to increased desirable MUFA and a concomitant reduction in the undesirable SFA in milk (Reh et al., 2004). Peterson et al. (2002) reported individual animal differences in SCD1 activity independent of dietary influences, suggesting the possibility of within-breed selection for increased desaturase activity. Schennink et al. (2008) also reported heritabilities for different SCD indices in the range of 0.23 to 0.46 indicating substantial genetic variation for milk fat unsaturation.

Three SNP (A702G, T762C, and C878T) in total linkage disequilibrium have been identified in exon 5 of the bovine $S C D 1$ gene, and the C878T SNP results in 2 protein variants, A (293Ala) and V (293Val) (Taniguchi et al., 2004; Kgwatalala et al., 2007). The amino acid substitution (Ala293Val) lies within the catalytic site of the enzyme. Taniguchi et al. (2004) reported significant associations between Ala293Val SCD1 genotypes and the fatty acid composition of intramuscular fat in Japanese black cattle, and Schennink et al. (2008) reported significant associations between different SCD1 genotypes and individual fatty acid contents and various SCD1 indices in Dutch Holstein-Friesian heifers.

On the basis of the role of the SCD1 gene in fatty acid unsaturation and the differences in milk fat percentage between Holsteins and Jerseys, the objectives of our study were to investigate the effects of the SCD1 Ala293Val polymorphism and stage of lactation on individual fatty acids contents, various desaturation indices, and other milk composition traits in Canadian Jersey cows.

\section{MATERIALS AND METHODS}

\section{Experimental Animals}

The analysis was carried out on 525 first- to fifthparity Canadian Jersey cows from 17 herds in southern Quebec. The cows were from 21 to 350 DIM and were sired by 160 bulls ( 1 to 35 progeny per bull). Cows were enrolled in the Valacta Program (www.valacta.com) that routinely analyzes milk samples from participating dairy herds in Quebec. A single composite milk sample comprising the morning and evening milkings was collected for each cow for milk fatty acid determination and DNA extraction. Samples from participating herds were collected between January and October 2007.

\section{DNA Isolation from Milk}

Thirteen milliliters of the raw milk sample was centrifuged at $21,000 \times g$ at $4^{\circ} \mathrm{C}$ for $30 \mathrm{~min}$. The supernatant, including the fat layer, was aspirated and discarded, except for the bottom $1 \mathrm{~mL}$. Five hundred microliters of the sediment, which contained mostly somatic cells and casein, was then transferred into a clean 2-mL tube and washed 3 times with $800 \mu \mathrm{L}$ of $1 \times$ PBS solution. Each wash was followed by centrifugation at $15,000 \times$ $g$ for $5 \mathrm{~min}$ and removal of $800 \mu \mathrm{L}$ of the supernatant. After the final centrifugation, $400 \mu \mathrm{L}$ of sediment was resuspended in $500 \mu \mathrm{L}$ of the extraction buffer $(\mathrm{pH} \mathrm{8.0;}$ $10 \mathrm{~m} M$ Tris, $150 \mathrm{~m} M \mathrm{NaCl}, 2 \mathrm{~m} M$ EDTA, and $1 \%$ $\mathrm{SDS}$ ) and $25 \mu \mathrm{L}$ of proteinase $\mathrm{K}$ (Invitrogen Canada Inc., Burlington, Ontario, Canada). The samples were incubated overnight at $65^{\circ} \mathrm{C}$ and were left to cool at room temperature. Seven hundred microliters of phenolchloroform (1:1 ratio) mixture (Invitrogen Canada Inc.) was added to the lysate before centrifugation at 13,400 $\times g$ for $15 \mathrm{~min}$. The phenol-chloroform and centrifugation steps above were repeated 2 more times on the clear aqueous supernatant obtained after centrifugation. The final clear aqueous supernatant obtained after the last centrifugation was then used to precipitate the DNA by addition of $800 \mu \mathrm{L}$ of $100 \%$ ethanol kept at $-20^{\circ} \mathrm{C}$, followed by centrifugation at $13,400 \times g$ for $5 \mathrm{~min}$. The resulting DNA pellet was then washed 3 times with $70 \%$ ethanol followed by a final DNA elution step in Tris EDTA buffer.

\section{SCD1 Genotyping with PCR-RFLP Method}

The Ala293Val polymorphism in exon 5 of the $S C D 1$ gene was genotyped in 525 cows by the method of PCR-RFLP. Primers were designed based on GenBank accession no. AY241932 and used to amplify a 400-bp fragment that included exon 5. The PCR amplifications were performed with a programmable thermal cycler, PTC-100 (MJ-Research Inc., Watertown, MA) in a final reaction volume of $25 \mu \mathrm{L}$ using PCR reagents from Invitrogen. The PCR reaction mix contained $50 \mathrm{ng}$ of genomic DNA, $0.2 \mathrm{~m} M$ dNTPs, $2.25 \mathrm{mM} \mathrm{MgCl}_{2}, 0.6$ $\mu M$ each primer, and 1.5 units of Taq DNA polymerase. Primer sequences were: forward primer, $5^{\prime}$-CCC ATT CGC TCT TGT TCT GT-3'; reverse primer, 5'-CGT GGT CTT GCT GTG GAC T-3'. After an initial de- 
naturation step of $94^{\circ} \mathrm{C}$ for $3 \mathrm{~min}$, the reaction mix was subjected to the following cycling conditions: 34 cycles of $94^{\circ} \mathrm{C}$ for $45 \mathrm{~s}, 54^{\circ} \mathrm{C}$ for $30 \mathrm{~s}$, and $72^{\circ} \mathrm{C}$ for 1 min $30 \mathrm{~s}$, plus a final extension step of $72^{\circ} \mathrm{C}$ for $10 \mathrm{~min}$. Amplification was confirmed by running the PCR products on $2 \%$ agarose gels and visualizing under UV light after staining with ethidium bromide.

The PCR products were digested at $37^{\circ} \mathrm{C}$ overnight with 10 units of $N c o$ I nuclease (New England BioLabs Inc., Pickering, Ontario, Canada) based on the A702G polymorphism, which is in complete linkage equilibrium with the C878T (Ala293Val) polymorphism, resulting in two 200-bp fragments for the AA genotype, 400- and 200-bp fragments for the AV genotype, and the undigested 400-bp fragments for the VV genotype. The digested products were separated on $2 \%$ agarose gels stained with ethidium bromide and visualized and scanned using an FX Phosphoimager (Bio-Rad Laboratories Inc., Hercules, CA).

\section{Milk Composition}

Test-day milk fat, protein, and lactose contents were determined on fresh milk samples using MilkoScan FT 6000 Series mid-range infrared Fourier transform infrared-based spectrometers (Foss Electric, Hillerød, Denmark), and the SCC were determined by means of Fossomatic flow cytometric cell counter (Foss Electric) at Valacta (Ste-Anne-De-Bellevue, Quebec). Testday milk fat and protein yields were determined by multiplying the respective percentages with the total test-day milk production. Production parameters for the entire lactation (305-d total milk production, 305-d milk fat yield and milk protein yield) were provided by Valacta.

\section{Determination of Fatty Acids}

Lipid extraction was performed according to Hara and Radin (1978), and milk fatty acids were transesterified with sodium methoxide according to the method of Christie (1982) with modifications as described by Chouinard et al. (1999). The C17:0 methyl ester (NuChek Prep Inc., Elysian, MN) was used as the internal standard. Fatty acid methyl esters in hexane were then injected (split inlet 100:1) into a GC (Varian, CP 3900 GC, Walnut Creek, CA) equipped with a flameionization detector. Separation of fatty acid methyl esters was performed with a Supelco 100-m fused-silica capillary column $(100 \mathrm{~m} \times 0.25 \mathrm{~mm} \times 0.2-\mu \mathrm{m}$ film thickness; Supelco, Bellefonte, PA). Helium was used as carrier gas at a constant flow of $1 \mathrm{~mL} / \mathrm{min}$. Oven temperature was programmed from 60 to $165^{\circ} \mathrm{C}$ at $3^{\circ} \mathrm{C} /$ min and held for 10 min followed by an increase to $220^{\circ} \mathrm{C}$ at $5^{\circ} \mathrm{C} / \mathrm{min}$ and held for $28 \mathrm{~min}$. Injector and detector were set at 250 and $255^{\circ} \mathrm{C}$, respectively. The gas chromatograph calculated peak areas for individual fatty acids automatically, and each peak was identified and quantified by comparison with pure methyl ester standards (Nu-Chek Prep Inc.).

\section{Desaturase Indices}

Desaturase indices were determined by calculating the ratios of cis-9 unsaturated to $c i s-9$ unsaturated + saturated for specific fatty acid pairs and multiplied by 100 (Kelsey et al., 2003). The following indices were calculated: C10 index (C10I), C12 index (C12I), C14 index (C14I), C16 index (C16I), C18 index (C18I), conjugated linoleic acid index (CLAI). The total desaturase index was calculated according to Mele et al. (2007):

$$
\begin{aligned}
& \text { Total index }=(\mathrm{C} 10: 1+\mathrm{C} 12: 1+\text { cis-9 C14:1 + cis-9 } \\
& \text { C16:1 + cis-9 C18:1 + cis-9, trans-11 CLA }) /(\mathrm{C} 10: 1 \\
& +\mathrm{C} 12: 1+\text { cis-9 C14:1 + cis-9 C16:1 + cis-9 C18:1 } \\
& + \text { cis-9, trans-11 CLA + C10:0 + C12:0 + C14:0 } \\
& \text { + C16:0 + C18:0 + trans-11 C18:1) × 100. }
\end{aligned}
$$

\section{Statistical Analysis}

Data were analyzed with SAS software (version 9.2.1, SAS Institute, Cary, NC) using PROC MIXED (Littell et al., 2006) and the following model:

$$
\begin{gathered}
\mathrm{Y}_{\mathrm{ijklm}}=\mu+\operatorname{HERD}_{\mathrm{i}}+\text { PARITY }_{\mathrm{j}}+\mathrm{DIM}_{\mathrm{k}}+\mathrm{SCD}_{\mathrm{l}} \\
+\mathrm{SIRE}_{\mathrm{m}}+\varepsilon_{\mathrm{ijklm}},
\end{gathered}
$$

where $Y_{i j k l m}=$ dependent variable or measurable milk composition trait; $\mu=$ overall mean; $\mathrm{HERD}_{\mathrm{i}}=$ fixed effect of the $i$ th herd (17 herds); PARITY ${ }_{j}=$ fixed effect of the $j$ th parity (first, second, third, fourth or greater): $\mathrm{DIM}_{\mathrm{k}}=$ fixed effect of the $k$ th DIM interval (3 intervals; $<100=$ early lactation, $100-200=$ mid lactation, $>200=$ late lactation); $\mathrm{SCD}_{1}=$ fixed effect of the $l$ th SCD genotype (AA, AV, VV); Sire $_{\mathrm{m}}=$ random effect of the $m$ th sire $(160$ sires $)$; and $\varepsilon_{\mathrm{jklm}}=$ random residual effect. All interactions among various fixed variables were included in the initial model and were eventually dropped from the final model because they were not significant.

Results on the $S C D$ genotype effects are presented as least squares means $\pm \mathrm{SE}$, and means separation was by paired $t$-test with Scheffe's adjustment. Differences between means were declared significant at $P \leq 0.05$. 


\section{RESULTS AND DISCUSSION}

\section{Effects of SCD1 Genotypes on Fatty Acid Profiles and Desaturase Indices}

A total of 525 Canadian Jersey cows were genotyped at the $S C D 1$ locus, and the genotypic frequencies were $0.686,0.244$, and 0.070 for the AA, AV, and VV genotypes, respectively. The frequency of the $A$ allele was 0.808 and that of $V$ allele was 0.192 . Genotype frequencies were in Hardy-Weinberg equilibrium, clearly indicating random mating with respect to this locus in Canadian Jersey cows. The relatively high frequency of $A$ allele confirms an earlier report by Kgwatalala et al. (2007) on a small sample involving 48 Jersey cows.

Moioli et al. (2007) calculated allele frequencies at the SCD1 locus of 3 different Italian breeds and also reported a relatively high frequency of the $A$ allele in Italian Jersey cows (0.94 vs. 0.06 for the $V$ allele). A higher frequency of the $A$ allele relative to the $V$ allele has also been reported in the Valdostana (0.65) but not in the Piedmontese (0.42), which had a relatively high frequency (0.58) of the $V$ allele (Moioli et al., 2007).

The influence of different $S C D 1$ genotypes on the milk fatty acid profile of Canadian Jerseys is presented in Table 1. The SCD1 genotype had a significant influence on $\mathrm{C} 10: 1$ and $\mathrm{C} 12: 1$ but had no significant influence on the proportion of short-chain (C4:0 to C8:0) and longchain (C18) fatty acids in milk fat of Canadian Jersey cows. In comparison with the $V$ allele, the $A$ allele was associated with significantly greater proportions of C10:1 and C12:1 and numerically lower, but nonsignificant, proportions of the saturated counterparts of the same fatty acids (C10:0, C12:0). There were, however, no significant differences between the homozygous AA and heterozygous AV cows in the proportions of $\mathrm{C} 10: 1$ and C12:1 fatty acid in milk fat. The difference in the proportions of C14:1 between homozygous AA and homozygous VV approached significance $(P=0.054)$. In line with our findings, Schennink et al. (2008) reported a significant positive effect of the $S C D 1 A$ allele on the relative proportions of $\mathrm{C} 10: 1, \mathrm{C} 12: 1$, and $\mathrm{C} 14: 1$ in a population of 1,933 Dutch Holstein-Friesian heifers. Schennink et al. (2008) also reported a significant negative influence of the $A$ allele on the proportions of C10:0, C12:0, and C14:0 and our results indicate a similar trend, although the differences between the 2 alleles were not significant in our study $(P=0.221$ for C10:0; $P=0.278$ for $\mathrm{C} 12: 0 ; P=0.754$ for C14:0). Mele et al. (2007) reported a significant positive effect of the $A$ allele only in the proportion of C14:1 fatty acid in a group of 297 Italian Holstein-Friesian cows, whereas Moioli et al. (2007) reported a significant positive effect of the $A$ allele on C10:1 and C14:1 in Italian Valdostana and Piedmontese cows. In this study, the SCD1 genotype had no significant influence on the proportions of C16:1, C18:1, CLA, total saturated fatty acids, MUFA, and PUFA in Canadian Jersey cows. Our results were different from those reported for Holstein cows. Schennink et al. (2008) reported a significant positive effect of the $V$ allele on C16:1, C18:1, and CLA contents of milk fat of Dutch Holstein-Friesian heifers. Furthermore, Mele et al. (2007) reported a significant positive effect of the $A$ allele on the total MUFA content of milk fat of Italian Holstein-Friesian cattle.

The effects of different $S C D 1$ genotypes on different fatty acid desaturase indices are in Table 2. Lower desaturase indices (2.881 to 11.188 ) were found for medium-chain fatty acids (C10 to C16) and comparatively higher desaturase indices were found for long-chain fatty acids (C18). The SCD1 genotype had a significant effect on C10I, C12I, and C14I but no significant effect on C16I, C18I, CLAI, and total index. The homozygous AA genotype had the highest C10I, C12I, and C14I and the homozygous VV genotypes the lowest. There were significant differences in C10I, C12I, and C14I between the homozygous AA genotype and the homozygous VV genotype but the differences were not significant between the homozygous AA genotype and the heterozygote. Relative to the $V$ allele, the $A$ allele was thus associated with significantly higher C10I, C12I, and C14I and similar C16I, C18I, and CLAI. Our results are consistent with those of Moioli et al. (2007) who reported a favorable effect of the $A$ allele on C10I and C14I and no significant effects on other desaturase indices in Italian Valdostana and Piedmontese cows. Schennink et al. (2008) also found a significant positive effect of the $A$ allele on C10I, C12I, and C14I and a negative effect on C16I, C18I, and CLAI, although in our case, the differences in C16I, C18I, and CLAI between the $A$ and $V$ alleles were not significant. Mele et al. (2007) found a favorable effect of the $A$ allele on $\mathrm{C} 14 \mathrm{I}$ and no effect on other indices in the Italian Holstein-Friesian cows.

Differences on the effects of $S C D 1$ genotypes on the fatty acid profiles and desaturase indices between medium-chain fatty acids (C10 to C16) and long-chain fatty acids (C18) might be explained in part by the origin of milk fatty acids. The $S C D 1 A$ allele was found to have a significant positive effect on some of the mediumchain MUFA (C10:1, C12:1, and C14:1) and on some of the medium-chain desaturase indices (C10I, C12I, and C14I) and not on the long-chain fatty acid profile and desaturase index. It is commonly accepted that nearly all of the C4 to C14 fatty acids in milk and approximately half of the C16:0 in milk are synthesized de novo and the other half of C16:0 and nearly all of the long-chain fatty acids are derived from blood lipoproteins (Bau- 
Table 1. Effect of stearoyl-CoA desaturase $1(S C D 1)$ genotype on milk fatty acid profile (g/100 g of total fatty acids) of Canadian Jersey cows

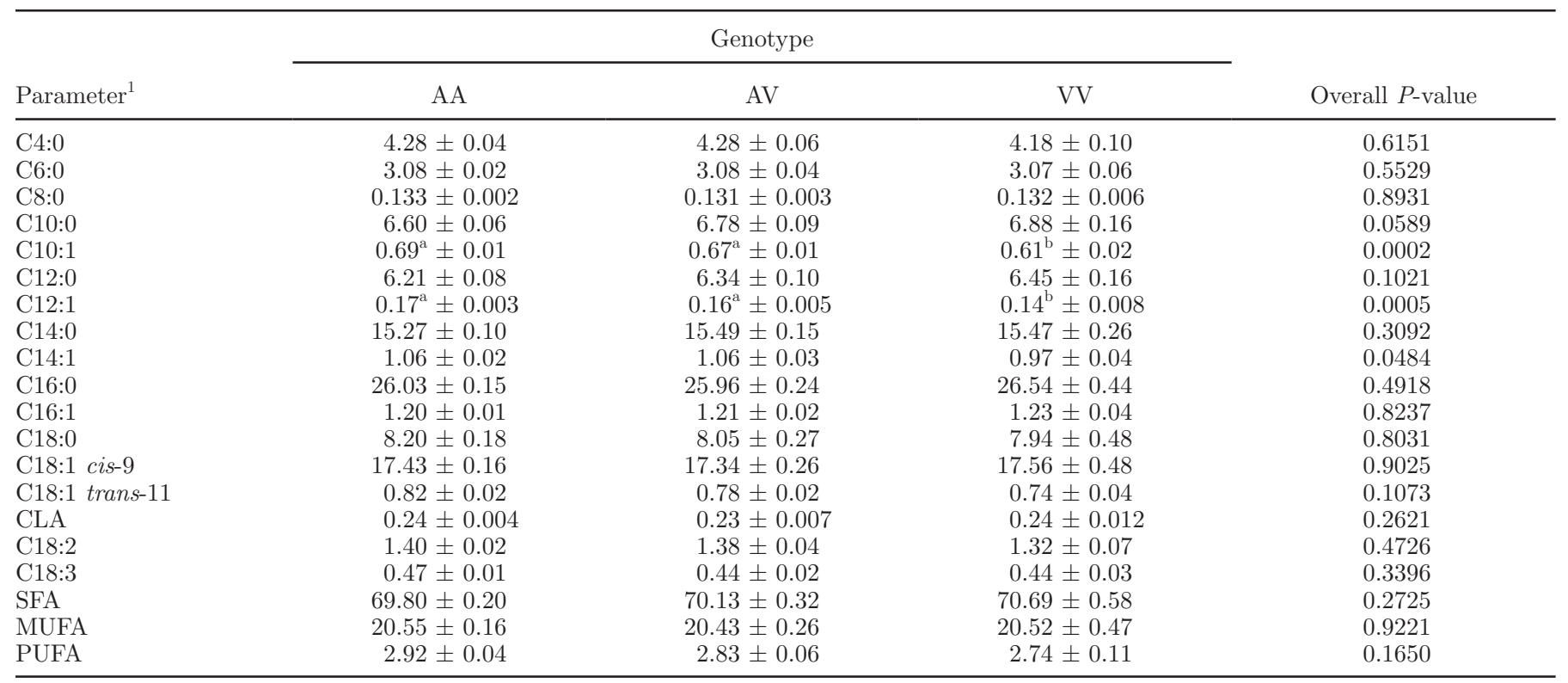

${ }^{\mathrm{a}, \mathrm{b}}$ Means within a row with different superscripts differ significantly $(P \leq 0.05)$.

${ }^{1} \mathrm{CLA}=$ conjugated linoleic acid; SFA = saturated fatty acids; MUFA = monounsaturated fatty acids; PUFA = polyunsaturated fatty acids.

man and Davis, 1974). The $A$ allele thus seems to have a positive effect only in the conversion of exclusively de novo synthesized medium-chain saturated fatty acids into their unsaturated counterparts in the mammary glands of ruminant animals. The favorable effect of the $A$ allele on medium-chain fatty acid unsaturation and desaturase indices is particularly interesting because saturated medium-chain fatty acids contribute most to the hypercholesterolemic effects on milk consumers (Grummer, 1991). Chilliard et al. (2000) noted a very low SCD1 activity with fatty acids shorter than 18-carbons that is consistent with our relatively lower desaturase indices (C10I to $\mathrm{C} 16 \mathrm{I}$ ) for medium-chain fatty acids and higher desaturase indices for long-chain fatty acids. Blood lipoproteins, which supply most of the long-chain fatty acids found in milk, derive fatty acids from the animal's diet or mobilization of adipose tissue fatty acids (Grummer, 1991). Intestinal SCD1 activity and adipose tissue SCD1 activity convert some of the dietary and adipose tissue saturated fatty acids into MUFA, which may then be incorporated into blood lipoproteins and eventually milk, leading to the high desaturase indices observed for long-chain fatty acids. The high desaturase indices for C18I and CLAI

Table 2. Effect of stearoyl-CoA desaturase 1 (SCD1) genotype on SCD1 indices in Canadian Jersey cows

\begin{tabular}{lrrrr} 
& \multicolumn{3}{c}{ Genotype } & \\
\cline { 2 - 4 } Parameter $^{1}$ & \multicolumn{1}{c}{ AA } & AV & VV & Overall $P$-value \\
\hline C10 index & $11.19^{\mathrm{a}} \pm 0.11$ & $10.68^{\mathrm{a}} \pm 0.17$ & $9.50^{\mathrm{b}} \pm 0.32$ & $<0.0001$ \\
C12 index & $2.88^{\mathrm{a}} \pm 0.05$ & $2.72^{\mathrm{a}} \pm 0.07$ & $2.29^{\mathrm{b}} \pm 0.13$ & $<.0001$ \\
C14 index & $8.14^{\mathrm{a}} \pm 0.17$ & $8.06^{\mathrm{ab}} \pm 0.22$ & $7.29^{\mathrm{b}} \pm 0.34$ & 0.0331 \\
C16 index & $5.88 \pm 0.07$ & $5.89 \pm 0.12$ & $5.95 \pm 0.21$ & 0.9487 \\
C18 index & $70.51 \pm 0.43$ & $70.94 \pm 0.65$ & $71.62 \pm 1.15$ & 0.5803 \\
CLA index & $26.43 \pm 0.41$ & $26.06 \pm 0.66$ & $28.78 \pm 1.20$ & 0.1242 \\
Total index & $24.80 \pm 0.18$ & $24.63 \pm 0.29$ & $24.54 \pm 0.53$ & 0.8106 \\
\hline
\end{tabular}

\footnotetext{
a,b Means within a row with different superscripts differ significantly $(P \leq 0.05)$.

${ }^{1}$ The $\mathrm{C} 10$ to $\mathrm{C} 18$ indices are calculated according to the following example: C16 index $=$ cis-9 C16:1/(cis-9 C16:1 + C16:0) $\times 100 ;$ conjugated linoleic acid $(\mathrm{CLA})$ index $=$ cis-9, trans-11 CLA $/$ cis-9, trans-11, CLA + trans-11 C18:1) $\times 100 ;$ total index $=(\mathrm{C} 10: 1+\mathrm{C} 12: 1+$ cis-9 C14:1 + cis-9 C16:1 + cis-9 C18:1 + cis-9, trans-11 CLA)/(C10:1 + C12:1 + cis-9 C14:1 + cis-9 C16:1 + cis-9 C18:1 + cis-9, trans-11 CLA + C10:0 + $\mathrm{C} 12: 0+\mathrm{C} 14: 0+\mathrm{C} 16: 0+\mathrm{C} 18: 0+$ trans-11 C18:1) $\times 100$.
} 
Table 3. Effects of stearoyl-CoA desaturase $1(S C D 1)$ genotype on routinely recorded lactation parameters in Canadian Jersey cows

\begin{tabular}{|c|c|c|c|c|}
\hline Parameter & \multicolumn{3}{|c|}{ Genotype } & Overall $P$-value \\
\hline Milk yield (kg) & $18.89 \pm 0.31$ & $18.76 \pm 0.43$ & $18.16 \pm 0.76$ & 0.6640 \\
\hline Fat $\%$ & $5.01 \pm 0.05$ & $5.16 \pm 0.06$ & $5.10 \pm 0.11$ & 0.0615 \\
\hline Protein yield (kg) & $0.72 \pm 0.01$ & $0.72 \pm 0.01$ & $0.70 \pm 0.03$ & 0.7525 \\
\hline Protein \% & $3.87 \pm 0.02$ & $3.93 \pm 0.03$ & $3.93 \pm 0.05$ & 0.0824 \\
\hline Lactose \% & $4.41 \pm 0.06$ & $4.40 \pm 0.06$ & $4.42 \pm 0.08$ & 0.8824 \\
\hline 305-d milk yield $(\mathrm{kg})$ & $5,875.98^{\mathrm{a}} \pm 111.86$ & $5,617.57^{\mathrm{ab}} \pm 137.10$ & $5,340.00^{\mathrm{b}} \pm 219.81$ & 0.0064 \\
\hline $305-\mathrm{d}$ fat yield $(\mathrm{kg})$ & $280.24 \pm 3.13$ & $271.90 \pm 4.81$ & $258.09 \pm 9.45$ & 0.0537 \\
\hline $305-\mathrm{d}$ protein vield $(\mathrm{kg})$ & $222.56^{\mathrm{a}} \pm 2.92$ & $213.98^{\mathrm{ab}} \pm 4.02$ & $204.32^{\mathrm{b}} \pm 7.32$ & 0.0120 \\
\hline
\end{tabular}

${ }^{\mathrm{a}, \mathrm{b}}$ Means within a row with different superscripts differ significantly $(P \leq 0.05)$.

could thus be a culmination of intestinal SCD1 activity, adipose tissue SCD1 activity, and mammary gland SCD1 activity.

\section{Effects of SCD1 Genotype on Routinely Recorded Milk Composition Traits}

We also investigated the effect of the Ala293Val polymorphism on traditionally recorded milk composition traits in Canadian Jersey cows for possible use of this polymorphism as a marker in selection programs, and the results are shown in Table 3. All the traits or parameters in Table 3 are test-day measures except for 305-d milk yield, 305-d fat yield, and 305-d protein yield, which cover the entire 305-d lactation period. The SCD1 genotype had no significant effects on all routinely recorded test-day measures (milk yield, fat percentage and yield, protein percentage and yield, SCC, MUN, and lactose percentage), but had an effect on 305-d total milk yield and 305-d total protein yield. The $A$ allele was associated with greater 305 -d protein and milk yields. Consistent with our results, Moioli et al. (2007) reported no significant effect of $S C D 1$ genotype on test-day fat and protein percentage, fat and protein yields, and milk yield.

Several independent studies have reported QTL for protein yield (Plante et al., 2001; Boichard et al., 2003) and milk yield (Boichard et al., 2003; Jiang et al., 2005) on the same chromosome where the $S C D 1$ gene has been mapped (Bos taurus autosome 26) and in close proximity to the $S C D 1$ gene. Causal mutations for these QTL effects might be in linkage disequilibrium with $S C D 1$

Table 4. Effect of stage of lactation (early, mid, and late) on the fatty acid profile ( $\mathrm{g} / 100 \mathrm{~g}$ of total fatty acids) of Canadian Jersey cows

\begin{tabular}{|c|c|c|c|c|}
\hline Parameter $^{1}$ & Early (<100 DIM) & $\operatorname{Mid}(100-200$ DIM) & Late $(>200$ DIM $)$ & Overall $P$-value \\
\hline $\mathrm{C} 4: 0$ & $4.40^{\mathrm{a}} \pm 0.07$ & $4.18^{\mathrm{b}} \pm 0.06$ & $4.16^{\mathrm{b}} \pm 0.06$ & 0.0007 \\
\hline C6:0 & $3.13^{\mathrm{a}} \pm 0.04$ & $3.04^{\mathrm{ab}} \pm 0.04$ & $3.02^{\mathrm{b}} \pm 0.03$ & 0.0325 \\
\hline C8:0 & $0.136 \pm 0.004$ & $0.131 \pm 0.003$ & $0.128 \pm 0.003$ & 0.1170 \\
\hline C10:1 & $0.58^{\mathrm{a}} \pm 0.01$ & $0.68^{\mathrm{b}} \pm 0.01$ & $0.70^{\mathrm{b}} \pm 0.01$ & $<0.0001$ \\
\hline $\mathrm{C} 12: 0$ & $6.10^{\mathrm{a}} \pm 0.11$ & $6.52^{\mathrm{b}} \pm 0.10$ & $6.40^{\mathrm{b}} \pm 0.10$ & 0.0002 \\
\hline $\mathrm{C} 12: 1$ & $0.14^{\mathrm{a}} \pm 0.01$ & $0.16^{\mathrm{b}} \pm 0.01$ & $0.17^{\mathrm{b}} \pm 0.01$ & $<0.0001$ \\
\hline $\mathrm{C} 14: 0$ & $14.89^{\mathrm{a}} \pm 0.16$ & $15.68^{\mathrm{b}} \pm 0.15$ & $15.66^{\mathrm{b}} \pm 0.14$ & $<0.0001$ \\
\hline C16:1 & $1.21 \pm 0.03$ & $1.22 \pm 0.02$ & $1.21 \pm 0.02$ & 0.8514 \\
\hline C18:0 & $8.37 \pm 0.30$ & $8.10 \pm 0.28$ & $7.72 \pm 0.25$ & 0.0888 \\
\hline C18:1 cis-9 & $18.68^{\mathrm{a}} \pm 0.29$ & $16.17^{\mathrm{b}} \pm 0.27$ & $17.49^{c} \pm 0.24$ & $<0.0001$ \\
\hline C18:1 trans-11 & $0.81 \pm 0.03$ & $0.76 \pm 0.02$ & $0.78 \pm 0.02$ & 0.3257 \\
\hline CLA & $0.22^{\mathrm{a}} \pm 0.01$ & $0.23^{\mathrm{ab}} \pm 0.01$ & $0.25^{\mathrm{b}} \pm 0.01$ & 0.0038 \\
\hline $\mathrm{C} 18: 2$ & $1.43 \pm 0.04$ & $1.33 \pm 0.04$ & $1.35 \pm 0.03$ & 0.0868 \\
\hline
\end{tabular}

${ }^{\mathrm{a}-\mathrm{C}}$ Means within a row with different superscripts differ $(P<0.05)$.

${ }^{1} \mathrm{CLA}=$ conjugated linoleic acid; SFA = saturated fatty acids; MUFA = monounsaturated fatty acids; PUFA = polyunsaturated fatty acids. 
Ala293Val polymorphism resulting in significant effect of $S C D 1$ genotype on 305-d milk and protein yields.

\section{Effects of Stage of Lactation on Fatty Acid Profiles and Desaturase Indices}

We tested the effects of parity and stage of lactation on desaturase indices and milk fatty acid composition of Canadian Jersey cows and found no significant effects of parity on desaturase indices and the contents of individual fatty acids in milk fat (results not shown). The influence of stage of lactation on the fatty acid profile of milk fat of Canadian Jersey cows is shown in Table 4. Stage of lactation significantly affected the proportions of short-chain fatty acids (C4:0 and C6:0), medium-chain fatty acids (C10:1, C12:0, C12:1, C14:0, C14:1, and C16:0), and long-chain fatty acids (C18:1 and CLA), but had no effect on C8:0; C10:0, C16:1, and $\mathrm{C} 18: 0$ contents. Greater contents of C4:0, C6:0, and C18:1 were observed in early lactation relative to other lactation stages, and the opposite was true for the contents of most of the medium-chain fatty acids (C10:1 to C16:0), which increased from early to mid lactation and remained constant until late lactation. Animals in late lactation produced milk fat with a significantly greater CLA content than that from animals at earlier lactation stages. The saturated fatty acid content increased from early to mid lactation and declined to earlylactation proportions during late lactation, whereas the opposite trends were observed for MUFA. The PUFA contents remained relatively constant throughout the whole lactation. Mele et al. (2007) also reported significantly lower contents of C14:0 and C14:1 and greater contents of C18:1 and MUFA in early lactation relative to other lactation stages in a group of 297 Italian Holstein-Friesian cows, but found no significant effect of stage of lactation on the content of C16:0. Consistent with our results, stage of lactation did not affect the contents of $\mathrm{C} 16: 1$ and $\mathrm{C} 18: 0$ in the Italian study and, contrary to our findings, had no significant effect on the CLA content. Kelsey et al. (2003) also found no significant effect of stage of lactation on the CLA content of Holstein and Brown Swiss cows. Auldist et al. (1998), however, reported an increase in the CLA content of milk fat from 7.9 to $9.7 \mathrm{mg} / \mathrm{g}$ of fatty acids from early to late lactation. A negative correlation has been reported between the proportions of de novo synthesized fatty acids (C6 to C12) and the proportions of C18 fatty acids in milk fat of dairy cattle (Palmquist et al., 1993; Stoop et al., 2008). During early lactation, cows may be in a negative energy balance, resulting in the mobilization of fatty acids including C18:1 from the adipose tissue and inhibition of de novo fatty acid synthesis, which might explain greater $\mathrm{C} 18: 1$ and lower contents of C10:1 to C16:0 during early lactation relative to the subsequent lactation stages. Consistent with our findings, Palmquist et al. (1993) reported an increase in the proportion of short- and medium-chain fatty acids (C6 to C16:0) with advancing lactation, accompanied by a compensatory decrease in the proportions of all C18 fatty acids. Oleic acid (C18:1) has a direct inhibitory effect on acetyl-CoA carboxylase, and the increased availability of C18:1 either from the diet or from adipose tissue mobilization in early lactation might decrease the percentage of de novo synthesized medium-chain fatty acids (C8:0 to C14:0) in milk fat (Barber et al., 1997; Natali et al., 2007). Removal of the inhibitory effect of C18:1 fatty acid with advancing lactation therefore results in increased contents of medium-chain fatty acids in milk fat.

Stage of lactation had a significant effect on all desaturase indices except C16I (Table 5). Early lactation was associated with significantly lower C10I, C12I, C14I, and CLAI than the subsequent lactation stages and the desaturase indices, which are an indirect measure of SCD1 activity, and were consistent with the contents of respective MUFA at different stages of lactation. The literature on the effect of stage of lactation on different

Table 5. Effect of stage of lactation on stearoyl-CoA desaturase 1 (SCD1) indices in Canadian Jersey cows

\begin{tabular}{lccrr}
\hline Parameter & Early $(<100$ DIM $)$ & Mid $(100-200$ DIM $)$ & Late $(>200$ DIM $)$ & Overall $P$-value \\
\hline C10 index & $9.29^{\mathrm{a}} \pm 0.19$ & $10.80^{\mathrm{b}} \pm 0.18$ & $11.20^{\mathrm{b}} \pm 0.16$ & $<.81^{\mathrm{b}} \pm 0.07$ \\
C12 index & $2.38^{\mathrm{a}} \pm 0.08$ & $2.70^{\mathrm{b}} \pm 0.07$ & $8.29^{\mathrm{b}} \pm 0.21$ & $<0.0001$ \\
C14 index & $7.38^{\mathrm{a}} \pm 0.23$ & $7.83^{\mathrm{ab}} \pm 0.22$ & $5.90 \pm 0.11$ & $<0.0001$ \\
C16 index & $6.01 \pm 0.13$ & $5.82 \pm 0.12$ & $72.06^{\mathrm{b}} \pm 0.61$ & 0.4373 \\
C18 index & $71.34^{\mathrm{ab}} \pm 0.71$ & $69.67^{\mathrm{a}} \pm 0.67$ & $27.96^{\mathrm{b}} \pm 0.61$ & 0.0036 \\
CLA index & $25.59^{\mathrm{a}} \pm 0.73$ & $27.72^{\mathrm{b}} \pm 0.67$ & $24.90^{\mathrm{c}} \pm 0.27$ & 0.0066 \\
Total index & $25.89^{\mathrm{a}} \pm 0.32$ & $23.17^{\mathrm{b}} \pm 0.29$ & $<0.0001$ \\
\hline
\end{tabular}

\footnotetext{
${ }^{\mathrm{a}-\mathrm{c}}$ Means within a row with different superscripts differ $(P \leq 0.05)$.

${ }^{1}$ Indices are calculated according to the following example: C16 index $=$ cis-9 C16:1/(cis-9 C16:1 + C16:0) $\times 100$; conjugated linoleic acid (CLA) index $=$ cis- 9, trans- 11 CLA $/($ cis-9, trans- 11, CLA + trans -11 C18:1 $) \times 100 ;$ total index $=(\mathrm{C} 10: 1+\mathrm{C} 12: 1+$ cis-9 C14:1 + cis-9 C16:1 + cis-9 $\mathrm{C} 18: 1+$ cis-9, trans-11 CLA $) /(\mathrm{C} 10: 1+\mathrm{C} 12: 1+$ cis-9 C14:1 + cis-9 C16:1 + cis-9 C18:1 + cis-9, trans-11 CLA + C10:0 + C12:0 + C14:0 + $\mathrm{C} 16: 0+\mathrm{C} 18: 0+$ trans-11 C18:1) $\times 100$.
} 
desaturase indices is very limited and, contrary to our findings, Kelsey et al. (2003) reported very little effect of stage of lactation on CLAI in 113 Holstein and 106 Brown Swiss cows.

The changing patterns for SCD1 gene activities (estimated from desaturase indices) and its substrates (saturated fatty acids) were similar throughout the entire lactation, suggesting that substrate availability may be one of the limiting factors for the enzyme's activity. Lower SCD1 activity during early lactation relative to the subsequent stages, as reflected by most of the indices, is also likely to be related to mobilization of fatty acids from adipose tissue. Delbecchi et al. (2001) hypothesized that mammary $S C D 1$ gene expression may be regulated by the different $\mathrm{C} 18: 1 / \mathrm{C} 18: 0$ ratios brought to the mammary gland by blood lipids. Linoleic acid (C18:2) and C18:3 as well as other long-chain PUFA are known inhibitors of SCD1 (Ntambi, 1999) but in our study, their proportions remained relatively constant throughout the entire lactation, eliminating their possible influence on SCD1 activity throughout lactation.

\section{CONCLUSIONS}

We have demonstrated that the $A$ allele of the $S C D 1$ gene positively influenced the unsaturation of C10:0 into C10:1, C12:0 into C12:1, and C14:0 into C14:1. However, the $A$ allele had no significant influence on the unsaturation of C16:0 into C16:1 and C18:0 into C18:1 in Canadian Jersey cows. This study suggests that the A293V polymorphism could be used as a marker for genetic selection for increased unsaturation of C10:0, C12:0, and C14:0 in Canadian Jersey cows. Increased unsaturation of $\mathrm{C} 10: 0, \mathrm{C} 12: 0$, and C14:0 will be beneficial for human health but the effects of such increased unsaturation on other traits will have to be evaluated. Stage of lactation had a significant influence on the fatty acid composition of milk fat and the contents of most medium-chain fatty acids (C10 to C16) and CLA increased from early to mid lactation and remained constant through to late lactation.

\section{ACKNOWLEDGMENTS}

The authors thank Robert Moore and Brian Corrigan at Valacta for organizing sample collections. We would also like to thank Benjamin Olaniyan at McGill for assisting with the preparation of fatty acid methyl esters and Roger Cue at McGill for his expert advice on statistical analysis. This study was supported by the Dairy Cattle Genetics Research and Development Council of Canadian Dairy Network and the Natural Sciences and Engineering Research Council of Canada.

\section{REFERENCES}

Auldist, M. J., B. J. Walsh, and N. A. Thomson. 1998. Seasonal and lactation influences on bovine milk composition in New Zealand. J. Dairy Res. 65:401-411.

Barber, M. C., R. A. Clegg, M. T. Travers, and R. G. Vernon. 1997. Lipid metabolism in the lactating mammary gland. Biochim. Biophys. Acta 1347:101-126.

Bauman, D. E., and C. L. Davis. 1974. Biosynthesis of milk fat. Page 31 in Lactation, a comprehensive treatise. Vol. 2. B. L. Larson and R. Smith, ed. Academic Press, New York, NY.

Boichard, D., C. Grohs, F. Bourgeois, F. Cerqueira, R. Faugeras, A. Neau, R. Rupp, Y. Amigues, M. Y. Boscher, and H. Leveziel. 2003. Detection of genes influencing economic traits in three French dairy cattle breeds. Genet. Sel. Evol. 35:77-101.

Bonanome, A., and S. M. Grundy. 1988. Effect of dietary stearic acid on plasma cholesterol and lipoprotein levels. N. Engl. J. Med. 318:1244-1248.

Chilliard, Y., A. Ferlay, R. M. Mansbridge, and M. Doreau. 2000. Ruminant milk fat plasticity; nutritional control of saturated, polyunsaturated, trans and conjugated fatty acids. Ann. Zootech. 49:181-205.

Chilliard, Y., A. Ferlay, J. Rouel, and G. Lamberet. 2003. A review of nutritional and physiological factors affecting goat milk lipid synthesis and lipolysis. J. Dairy Sci. 86:1751-1770.

Chouinard, P. Y., L. Corneau, A. Saebo, and D. E. Bauman. 1999. Milk yield and composition during abomasal infusion of conjugated linoleic acids in dairy cows. J. Dairy Sci. 82:2737-2745.

Christie, W. W. 1982. A simple procedure for rapid transmethylation of glycerolipids and cholesterol esters. J. Lipid Res. 23:10721075 .

Delbecchi, L., C. E. Ahnadi, J. J. Kennelly, and P. Lacasse. 2001. Milk fatty acid composition and mammary lipid metabolism in Holstein cows fed protected or unprotected canola seeds. J. Dairy Sci. 84:1375-1381.

German, J. B., L. Monrad, C. J. Dillard, and R. Xu. 1997. Milk fat composition: Targets for alteration of function and nutrition. Pages 35-72 in Milk Composition, Production, Biotechnology. R. A. S. Welch, D. J. W. Burns, S. R. Davis, A. I. Popay, and C. J. Prosser, ed. CAB International, Wallingford, UK.

Goddard, M. 2001. Genetics to improve milk quality. Aust. J. Dairy Technol. 56:166-170.

Grummer, R. R. 1991. Effect of feed on composition of milk fat. J. Dairy Sci. 74:3244-3257.

Hara, A., and N. S. Radin. 1978. Lipid extraction of tissues with low toxicity solvent. Anal. Biochem. 90:420-426.

Hayes, K. C., and D. R. Khosla. 1992. Dietary fatty acid thresholds and cholesterolemia. FASEB J. 6:2600-2607.

Jiang, Z., S. De, M. D. Garcia, K. B. Griffin, X. L. Wu, Q. Xiao, J. J. Michal, B. S. Sharma, and G. B. Jansen. 2005. An independent confirmation of a quantitative trait locus for milk yield and composition traits on bovine chromosome 26. J. Anim. Breed. Genet. 122:281-284.

Kelsey, J. A., B. A. Corl, R. J. Collier, and D. E. Bauman. 2003. The effect of breed, parity and stage of lactation on conjugated linoleic acid (CLA) in milk fat from dairy cows. J. Dairy Sci. $86: 2588-2597$.

Kgwatalala, P. M., E. M. Ibeagha-Awemu, J. F. Hayes, and X. Zhao. 2007. Single nucleotide polymorphisms in the open reading frame of the stearoyl-CoA desaturase gene and the resulting genetic variants in Canadian Holstein and Jersey cows. DNA Seq. 18:357-362.

Kris-Etherton, P. M., T. A. Pearson, Y. Wan, R. L. Hargrove, K. Moriarty, V. Fishell, and T. D. Etherton. 1999. Highmonounsaturated fatty acid diets lower both plasma cholesterol and triacylglycerol concentrations. Am. J. Clin. Nutr. 70:1009 1015.

Kromhout, D., A. Menotti, H. Kestleloot, and S. Sans. 2002. Prevention of coronary heart disease by diet and lifestyle: Evidence from prospective cross-cultural, cohort, and interventional studies. Circulation 105:893-898. 
Littell, R. C., G. A. Milliken, W. W. Stroup, R. D. Wolfinger, and O. Schabenberger. 2006. SAS for Mixed Models. 2nd ed. SAS Institute, Cary, NC.

MacDonald, H. B. 2000. Conjugated linoleic acid and disease prevention: A review of current knowledge. J. Am. Coll. Nutr. 19:111S-118S.

Mele, M., G. Conte, B. Castiglioni, S. Chessa, N. P. P. Macciotta, A. Serra, A. Buccioni, G. Pagnacco, and P. Secchiari. 2007. Stearoylcoenzyme A desaturase gene polymorphism and milk fatty acid composition in Italian Holsteins. J. Dairy Sci. 90:4458-4465.

Mensink, R. P., P. L. Zock, A. D. Kester, and M. B. Katan. 2003. Effects of dietary fatty acids and carbohydrates on the ration of serum total to HDL cholesterol and on serum lipids and apolipoproteins: A meta-analysis of 60 controlled trials. Am. J. Clin. Nutr. 77:1146-1155.

Moioli, B., G. Contarini, A. Avalli, G. Catillo, L. Orru, G. De Matteis, G. Masoero, and F. Napolitano. 2007. Short communication: Effect of stearoyl-coenzyme A desaturase polymorphism on fatty acid composition of milk. J. Dairy Sci. 90:3553-3558.

Natali, F., L. Siculella, S. Salvati, and G. V. Gnoni. 2007. Oleic acid is a potent inhibitor of fatty acid and cholesterol synthesis in C6 glioma cells. J. Lipid Res. 48:1966-1975.

Ntambi, J. M. 1999. Regulation of stearoyl-CoA desaturase by polyunsaturated fatty acids. J. Lipid Res. 40:1549-1558.

Palmquist, D. L., A. D. Beaulieu, and D. M. Barbano. 1993. Feed and animal factors influencing milk fat composition. J. Dairy Sci. $76: 1753-1771$

Pariza, M. W., Y. Park, and M. E. Cook. 1999. Conjugated linoleic acid and the control of cancer and obesity. Toxicol. Sci. 52(Suppl.):107-110

Parodi, P. W. 1999. Conjugated linoleic acid and other anticarcinogenic agents of bovine milk fat. J. Dairy Sci. 82:1339-1349.

Pascal, G. 1996. Les apports quotidiens recommandes en lipids et en acides gras. Oleagineaux Corps Gras Lipides 3:205-210.
Peterson, D. G., J. A. Kelsey, and D. E. Bauman. 2002. Analysis of variation in cis-9, trans-11 conjugated linoleic acid (CLA) in milk fat of dairy cows. J. Dairy Sci. 85:2164-2172.

Plante, Y., J. P. Gibson, J. Nadesalingam, H. Mehrabani-Yeganeh, S. Lefebvre, G. Andervoort, and G. B. Jansen. 2001. Detection of quantitative trait loci affecting milk production traits on 10 chromosomes in Holstein cattle. J. Dairy Sci. 84:1516-1524.

Reh, W.A., E. A. Maga, N. M. B. Collette, A. Moyer, J. S. ConradBrink, S. J. Taylor, E. J. DePeters, S. Oppenheim, J. D. Rowe, R. H. BonDurant, G. B. Anderson, and J. D. Murray. 2004. Hot Topic: Using a stearoyl- CoA desaturase transgene to alter milk fatty acid composition. J. Dairy Sci. 87:3510-3514.

Schennink, A., J. M. L. Heck, H. Bovenhuis, M. H. P. W. Visker, H. J. F. Van Valenberg, and J. A. M. van Arendonk. 2008. Milk fatty acid unsaturation: Genetic parameters and effects of stearoyl-CoA desaturase (SCD1) and acyl CoA:diacylglycerol acyltransferase 1 (DGAT1). J. Dairy Sci. 91:2135-2143.

Soyeurt, H., P. Dardenne, A. Gillion, C. Croquet, S. Vanderick, P. Mayeres, C. Bertozzi, and N. Gengler. 2006. Variation in fatty acid contents of milk and milk fat within and across breeds. J. Dairy Sci. 89:4858-4865

Stoop, W. M., J. A. M. van Arendonk, J. M. L. Heck, H. J. F. van Valenberg, and H. Bovenhuis. 2008. Genetic parameters for major milk fatty acids and milk production traits of Dutch HolsteinFriesians. J. Dairy Sci. 91:385-394.

Taniguchi, M., T. Utsugi, K. Oyama, H. Manmen, M. Kobayashi, Y. Tanabe, A. Ogino, and S. Tsuji. 2004. Genotype of stearoyl-CoA desaturase is associated with fatty acid composition in Japanese Black Cattle. Mamm. Genome 14:142-148.

Williams, C. M. 2000. Dietary fatty acids and human health. Ann. Zootech. 49:165-180. 